\title{
Indisciplina na sala de aula: Utilizando novas metodologias de ensino para melhorar a relação professor-aluno
}

\author{
Amanda G. da Silva Veruska F. F. de Almeida \\ Universidade Federal de Alagoas, UFAL \\ Campus de Arapiraca, Arapiraca-AL. \\ E-mail: veruskaldm@ hotmail.com
}

José da Silva Barros

Universidade Federal de Alagoas, UFAL

Campus de Arapiraca, Arapiraca, AL.

E-mail: barros199@gmail.com

Este trabalho foi feito através de pesquisas e intervenções feitas pelo PIBID (Programa Institucional de Iniciação à Docência de matemática da Universidade Federal de Alagoas (UFAL), no qual foram aplicados algumas novas metodologias de ensino para diminuir a indisciplina nas aulas de matemática. A indisciplina, de maneira geral, é algo que circunda o meio escolar há muito tempo e a sala de aula torna-se um campo de batalha entre professores e alunos, causando obstáculos no processo de ensino-aprendizagem. Percebemos através das pesquisas feitas que a falta de aulas dinâmicas, a má comunicação entre professor-aluno e também a utilização de métodos tradicionais de educação são os principais fatores que contribuem para a indisciplina em sala de aula. Também percebemos que o aluno indisciplinado melhora seu comportamento e desenvolve uma melhor compreensão durante a aplicação de novas metodologias usadas pelo professor. Assim, utilizamos novas metodologias, incluindo jogos e recursos tecnológicos para que os alunos se sentissem interessados em aprender o conteúdo e que pudessem discutir, debater com seus colegas e professor, diminuindo a indisciplina, melhorando a relação do professor-aluno e aumentando o rendimento escolar. Nosso objetivo foi intervir na realidade indisciplinar nas aulas de matemática, principalmente no Ensino Médio. Analisando a questão da indisciplina, temos que a educação ao decorrer do tempo vem questionando sobre qual deve ser o seu papel através de um olhar social, epistêmico e profissionalizante, tentando dessa maneira analisar o que estaria acontecendo com esses novos alunos. Segundo ESTRELA (2002) apud Ricardo Oliveira, os problemas de indisciplina representam um dos mais antigos e persistentes desafios encontrados nas escolas, em todos os países industrializados. A visão que se tinha da escola como um espaço que promove desenvolvimento humano está sendo substituída por um campo de batalha entre professor e aluno. "Os relatos dos professores testemunham que a questão disciplinar é, atualmente, uma das dificuldades fundamentais quanto ao trabalho escolar" (Aquino, 1996, p.40). A indisciplina atualmente está se transformando no principal obstáculo do professor, fazendo com que esses educadores repensem sobre o que estaria acontecendo com as práticas escolares a ponto de mudar a antiga concepção do termo pedagógico que caracteriza-se por uma metodologia restrita a resultado sem levar em consideração aulas práticas, diferenciadas, que estimulem os alunos a se interessar pela matéria (Tuleski,2005).

Falando da matemática, sabemos que esta disciplina exige muita atenção e dedicação para que seja entendida, e por isso é considerada pelos alunos uma das disciplinas mais difíceis, um bicho-de-sete-cabeças. Nos PCN's temos que o conhecimento matemático formalizado, precisa necessariamente, ser transformado para se tornar passível de ser ensinado/aprendido e que a aprendizagem não se dá com o indivíduo isolado, mas em uma vivência coletiva para que com essa vivência possa demonstrar alguma dificuldade que enfrenta. Esse trabalho foi dividido em duas etapas, a primeira foi o conhecimento das escolas e dos alunos e a segunda foi a intervenção. Para entender a concepção dos alunos e professores sobre indisciplina e metodologias de ensino, foram observadas aulas em algumas escolas em Arapiraca- AL e aplicados questionários para o professor e alunos considerados indisciplinados ou não, pertencentes a diferentes séries, começando pelo $6^{\circ}$ ano e se estendendo ao $3^{\circ}$ ano do Ensino Médio. Foram entrevistados alunos e professores, com perguntas relacionadas às causas da 
indisciplina, a relação professor-aluno e ao âmbito escolar envolvido com o familiar, concepções sobre indisciplina, e o que poderia ser feito para amenizar a indisciplina do ambiente escolar. Na segunda parte do trabalho, que foram as intervenções, utilizamos novas metodologias de ensino. Essas intervenções foram feitas nas escolas observadas para experiência, mas teve a maior concentração, por cerca de 2 anos, na Escola Estadual Isaura Antônia de Lisboa, escola vinculada ao PIBID de matemática da UFAL. Antes da aplicação da intervenção foram assistidas algumas aulas para entendermos a metodologia usada do professor e também para visualizarmos o motivo dessa tal indisciplina. Nesse período de observação foi o momento de interação entre os bolsistas do PIBID e os alunos e também constatamos que o docente usava o método tradicional de ensino, usando apenas o pincel e livro didático, tornando a aprendizagem algo mecânico, onde geralmente o aluno não participa e nem é estimulado a aprender por prazer. Assim foram feitas algumas atividades diferentes da que estavam acostumados para analisar como os alunos se comportavam durante sua aplicação e se havia a diminuição da indisciplina; em uma delas utilizamos o software Winplot, que é um programa para desenho e visualização de gráficos, em outra utilizamos a oficina de poliedros, e nas outras utilizamos os jogos, pois são fáceis de adaptar a qualquer situação e foram os seguintes: bingo das funções, o dominó de equações e o yoté das funções.

Com as intervenções na sala de aula através das novas metodologias de ensino, obtemos um excelente resultado, pois os alunos se dedicaram a responder cada equação proposta e se mostraram entusiasmados com as aulas diferentes. Percebemos que a dedicação era muito grande e a indisciplina não aconteceu, o que nós vimos foi um momento de interação e troca de conhecimentos. O trabalho realizado mostrou que uma das coisas que os alunos preferem são aulas dinâmicas e práticas utilizando as tecnologias, que é algo que nos dia de hoje os alunos tem grande facilidade não só de acesso, como também afinidade com tudo o que é novo e diferente, pois através destas aulas com auxilio de ferramentas tecnológicas os alunos indisciplinados fixam melhor o conhecimento e ainda se divertem. Em suma, com o uso das novas tecnologias, percebemos que as atividades desenvolvidas nesse trabalho não só diminuiu a indisciplina em sala de aula, mas também fez com que os alunos aprendessem os conteúdos que eles têm dificuldade. $\mathrm{O}$ uso de metodologias de ensino é uma forma de aumentar o rendimento dos alunos, fixando melhor o assunto passado em sala de aula. E ainda, ao estimular os alunos a se envolver nos assuntos trabalhados em sala de aula, podemos, além de mudar a imagem de alunos indisciplinados, prepará-los para atuar na sociedade, pois o professor está contribuindo para o real papel da educação, que é formar sujeitos preparados para agir na sociedade, não como alienados que aceitam tudo o que lhe é imposto, mas como sujeitos críticos, autônomos e conscientes de seus atos e suas ações na sociedade.

Palavras-chave: Indisciplina- Matemática- Novas metodologias

\section{Referências}

[1] Aquino, Julio Groppa. Indisciplina na escola: Alternativas teóricas e práticas. São Paulo: Sammus, 1996.

[2] Oliveira, Ricardo Augusto A de. Indisciplina na escola como fator determinante no processo ensino aprendizagem: a experiência da escola São Francisco em marco-CE. Disponível em:< http://www.artigonal.com/educacao-artigos/indisciplina-na-escola-como-fatordeterminante-no-processo-ensino-aprendizagem-a-experiencia-da-escola-sao-franciscoem-marco-ce-3138468.html > Acesso em 24/08/2012.

[3] Tuleski, Silvana C. Voltando o olhar para o professor: a psicologia e pedagogia caminhando juntas. Revista do Departamento de Psicologia, UFF vol.17 no.1 Niterói Jan./Junho2005. 